\title{
Possibility of Exosome-Based Therapeutics and Challenges in Production of Exosomes Eligible for Therapeutic Application
}

\author{
Takuma Yamashita, Yuki Takahashi,* and Yoshinobu Takakura \\ Graduate School of Pharmaceutical Sciences, Kyoto University; \\ 46-29 Yoshida-Shimo-Adachi, Sakyo-ku, Kyoto 606-8501, Japan. \\ Received February 16, 2018
}

\begin{abstract}
Exosomes are cell-derived vesicles with a diameter $30-120 \mathrm{~nm}$. Exosomes contain endogenous proteins and nucleic acids; delivery of these molecules to exosome-recipient cells causes biological effects. Exosomes derived from some types of cells such as mesenchymal stem cells and dendritic cells have therapeutic potential and may be biocompatible and efficient agents against various disorders such as organ injury. However, there are many challenges for the development of exosome-based therapeutics. In particular, producing exosomal formulations is the major barrier for therapeutic application because of their heterogeneity and low productivity. Development and optimization of producing methods, including methods for isolation and storage of exosome formulations, are required for realizing exosome-based therapeutics. In addition, improvement of therapeutic potential and delivery efficiency of exosomes are important for their therapeutic application. In this review, we summarize current knowledge about therapeutic application of exosomes and discuss some challenges in their successful use.
\end{abstract}

Key words exosome; therapeutic application; production

\section{INTRODUCTION}

Almost all cells secrete extracellular vesicles including exosomes, microvesicles, and apoptotic bodies. Exosomes are the smallest extracellular vesicles. Although the definition of exosomes is not clearly established, they are negatively charged lipid bilayer vesicles whose diameter is $30-100 \mathrm{~nm}$ and their density is $1.13-1.19 \mathrm{~g} / \mathrm{mL} .^{1)}$ Exosomes are secreted by fusion of multivesicular body (MVB) containing exosomes with plasma membrane. MVBs are formed by budding of intraluminal vesicles into late endosomes. ${ }^{2)}$ This process is regulated by a protein machinery known as endosomal sorting complex required for transport (ESCRT). ${ }^{3,4)}$ An ESCRT-independent MVB formation that requires ceramide has also been reported. ${ }^{5)}$ It has been shown that proteins other than ESCRT such as ARF6, PLD2, and sphingosine 1-phosphate receptor are related to biogenesis of exosomes. ${ }^{6,7)}$

Several molecules including lipids, proteins, and nucleic acids of producing cells are sorted to exosomes (Fig. 1). Although mechanisms of cargo loading into exosomes are not clear, it has been reported that RNA-binding proteins ${ }^{8,9)}$ and modification of protein such as ubiquitination, ${ }^{10)}$ sumoylation, ${ }^{8)}$ and glycosylation ${ }^{11)}$ are related to these processes. The composition of exosomal proteins is different among cell types. However, it is known that some proteins such as CD9, CD63, and Alix are enriched in exosomes and these proteins are currently used as exosome markers. ${ }^{12}$ Exosomes contain mRNA and short RNAs including microRNAs (miRNAs). ${ }^{13,14)}$ Lipidomic studies showed that cholesterol, sphingomyelin, glycosphingolipids, and phosphatidylserine are enriched in exosomes. ${ }^{5,15,16)}$

Exosomes induce many biological events by delivering bioactive molecules contained in exosomes. It has been reported that exosomes play important roles in intercellular transport in various pathological conditions such as cancer, ${ }^{17-20)}$ cardiovas- cular diseases, ${ }^{21)}$ diabetes, ${ }^{22)}$ and Alzheimer's disease. ${ }^{23)}$ Hence exosomes may be expected to become therapeutic targets in these diseases. Additionally, exosomes may be useful as diagnostic markers. Because of their endogenous origin, exosomes are expected to be safe therapeutic agents. In this review, current knowledge about the therapeutic potential of exosomes is summarized and challenges in producing exosomes eligible for therapeutic application are discussed.

\section{THERAPEUTIC APPLICATION OF EXOSOMES}

2.1. Regenerative and Anti-inflammatory Therapies Mesenchymal stem cells (MSCs) which are well known to possess anti-inflammatory and regenerative effects, are the most commonly used source of exosomes. ${ }^{24)}$ It has been reported that MSC-derived exosomes are related to the therapeutic effects of MSCs. ${ }^{25,26)}$ Through the delivery of their components including miRNAs and proteins such as interleukin-10 (IL-10) and transforming growth factor- $\beta$, MSCderived exosomes inhibit expression of pro-inflammatory cytokines to exert anti-inflammatory effect and promote tissue regeneration by enhancing extracellular matrix remodeling. Therefore MSC-derived exosomes have therapeutic potential against various diseases such as cardiovascular disease, liver

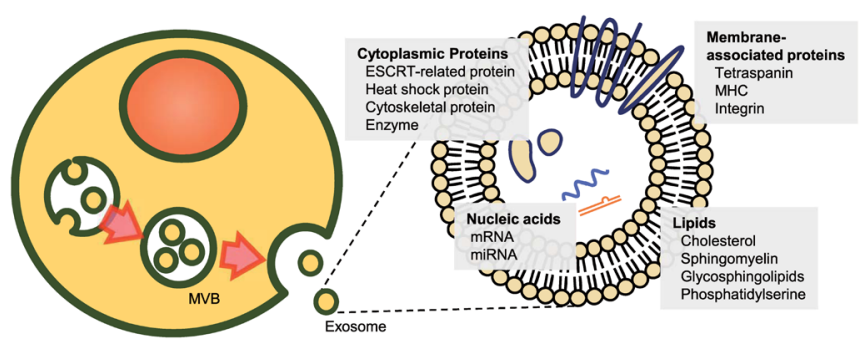

Fig. 1. Biogenesis and Composition of Exosomes 


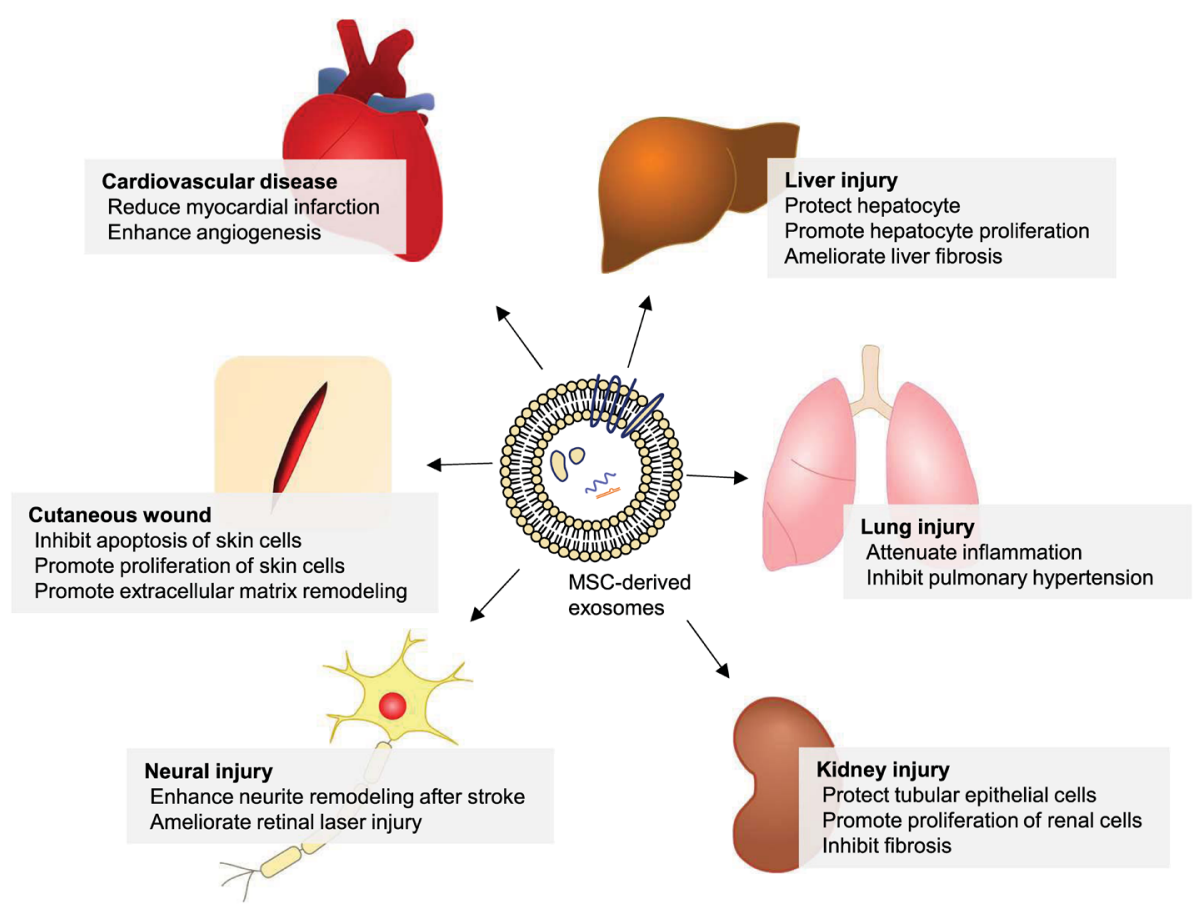

Fig. 2. Therapeutic Application of MSC-Derived Exosomes

injury, renal injury, and neural injury ${ }^{27-34)}$ (Fig. 2). Although MSCs themselves can be used to treat these diseases, therapeutics using MSC-derived exosomes seem a safer option. ${ }^{35}$ ) Exosome-based therapeutics have a lower risk for teratoma formation and embolization, which are major concerns for stem cell-based therapeutics. Exosomes secreted from induced pluripotent stem cell (iPS cell)-derived MSC also may exert therapeutic effects. ${ }^{36)}$ Therefore iPS cell-derived MSC can be a good source of exosomes since they can be abundantly prepared from patients. Moreover, exosomes secreted by iPS cell-derived MSC have superior therapeutic effect on osteoarthritis compared with the same number of exosomes secreted from synovial membrane-derived MSC. ${ }^{37)}$ It was shown that exosomes secreted from iPS cells, embryonic stem cells, and cardiac progenitor cells have therapeutic effects similar to MSC-derived exosomes. ${ }^{38-40)}$

Milk-derived exosomes have been shown to induce immunomodulatory effects. ${ }^{41-43)}$ Arntz et $a l .{ }^{42)}$ showed that oral administration of bovine milk-derived exosomes attenuate arthritis. It was also demonstrated that plant-derived exosome- like vesicles elicit immunomodulatory effects, although it is unclear whether these vesicles are strictly exosomes. ${ }^{44,45)} \mathrm{Im}$ munogenicity is a major concern of milk- and plant-derived exosomes because these are xenogeneic vesicles. Oral administration may be a safe route for the administration of these xenogeneic vesicles because they are derived from foods.

2.2. Cancer Vaccines Exosomes derived from dendritic cells (DCs) may be useful as anticancer vaccines because of the nature of DCs as antigen-presenting cells (APCs). Major histocompatibility complex (MHC)-I, MHC-II, and co-stimulating factor such as CD86 are expressed on the surface of DC-derived exosomes. ${ }^{46,47)}$ Administration of exosomes derived from DCs incubated with cancer antigen induced cancerspecific $\mathrm{T}$ cell response. ${ }^{48)}$ Although direct activation of $\mathrm{T}$ cells by surface proteins of exosomes has been reported, ${ }^{49)}$ the T-cell response is considered mainly induced by APCs that captured the exosomes. ${ }^{50)}$ It has been shown that mature DC-derived exosomes induced strong T-cell response compared with immature DC-derived exosomes. ${ }^{51)}$ In addition to antigen presentation, DC-derived exosomes activated natural

\section{Biography}

Takuma Yamashita was born in Gifu, Japan, in 1991. He obtained his B.S. degree at Faculty of Pharmaceutical Sciences, Kyoto University and pharmacist license in Japan in 2015. Now he is in the 4th year of the Ph.D. course at the Department of Biopharmaceutics and Drug Metabolism, Graduate School of Pharmaceutical Sciences, Kyoto University. He received the Nagai Memorial Research Scholarship from the Pharmaceutical Society of Japan for 2 consecutive years in 2015 and 2016. He has been a Research Fellow of the Japan Society for the Promotion of Science since 2017. His research focus is on the development of exosome-based therapeutics. He has investigated the biodistribution of injected exosomes, the major types of cells that are responsible for pharmacokinetics of

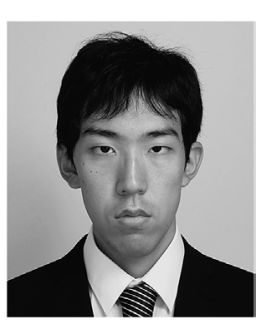

Takuma Yamashita exosomes, the effects of exosome isolation methods on the physicochemical and pharmacokinetic properties of exosomes, and an exosome-tropic RNA sequence for RNA loading into exosomes. Currently, his main research is focused on improving pharmacokinetic properties of exosomes. 


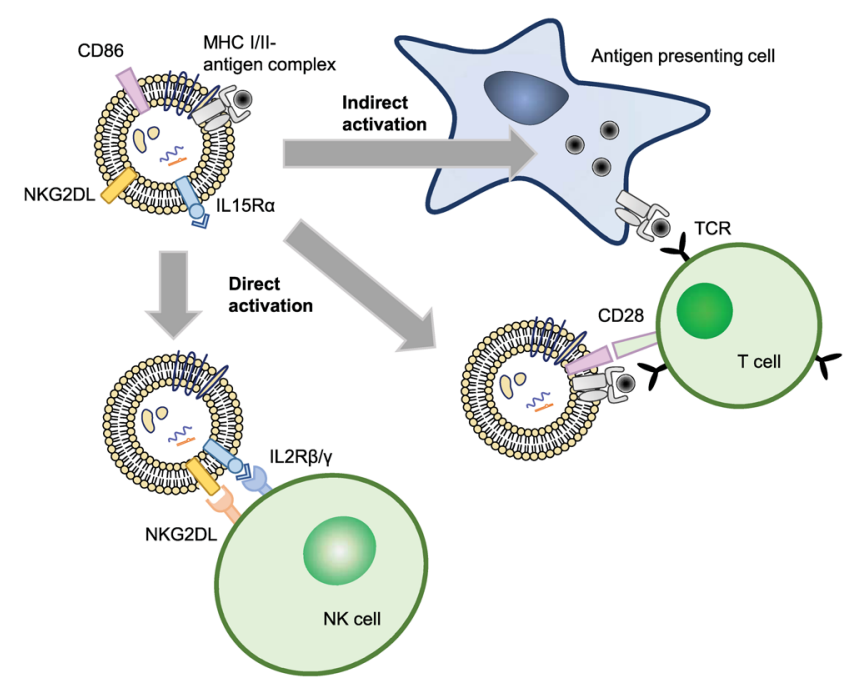

Fig. 3. Activation of T Cells and NK Cells by DC-Derived Exosomes

killer cells by their surface protein such as NKG2D ligand and IL-15R $\alpha^{52)}$ (Fig. 3).

Exosomes derived from cancer cells may also potentially be used as anticancer vaccines because they contain antigens. Our previous study showed that exosomes derived from B16BL6 murine melanoma containing melanoma antigens induced B16BL6-specific T-cell response and inhibited tumor growth. ${ }^{53,54)}$ On the other hand, it was reported that exosomes derived from cancer cells have roles on cancer progression, metastasis, and drug resistance. ${ }^{17-20)}$ Therefore safety evaluation is essential for using exosomes derived from cancer cells.

\section{CHALLENGES IN THE DEVELOPMENT OF EXO- SOME-BASED THERAPEUTICS}

3.1. Large-Scale Production One of the major problems for realizing exosome-based therapeutics is low productivity of exosomes. Yield of exosomes is typically less than $1 \mu \mathrm{g}$ exosomal protein from $1 \mathrm{~mL}$ of culture medium, ${ }^{55,56)}$ whereas the useful dose of exosomes is approximately $10-100 \mu \mathrm{g}$ exosomal protein/mouse in most studies. ${ }^{29,57)}$ Thus effective largescale exosome production methods are required.

Exosome-containing medium is normally prepared by culturing exosome-producing cells over a few days. Riches et $a .^{58)}$ and our preliminary data suggest that the amount of exosomes in culture medium reached upper limit after approximately 12 -h incubation, although the time until saturation is probably dependent on the types of producing cells. Bioreactor may be useful to improve yield of exosomes. Watson et al. ${ }^{59)}$ showed that yield of exosomes can be increased 5-10 fold using a hollow fiber bioreactor. However, whether yield of exosomes was actually increased by use of the bioreactor is not clear, since the obtained sample contained larger vesicles (200-800 $\mathrm{nm}$ in diameter).

Some reports demonstrated that exosome production was enhanced by applying stresses such as hypoxia, low $\mathrm{pH}$, and anticancer drugs on exosome-producing cells. ${ }^{60-62)}$ However, the therapeutic effects and safety of exosomes secreted from stressed cells should be carefully evaluated because it was demonstrated that cellular stresses change the composition of exosomal contents. ${ }^{60)}$ In addition, cellular stresses may increase contaminants derived from dead cells such as apoptotic bodies, which may cause adverse effects and overestimation of exosome amount.

Efficient isolation of exosomes is another approach to increase yield of exosomes. Our previous research showed a small difference in the yields of exosomes between three conventional ultracentrifugation-based isolation methods (simple ultracentrifugation, density cushion, and density gradient ultracentrifugation). ${ }^{56}$ In addition to the ultracentrifugationbased methods, other exosome-isolation methods have been developed. ${ }^{63-70)}$ Some of these methods such as size exclusion chromatography, ultrafiltration, aqueous two-phase system, and polymer-based precipitation can be used for large-scale production of exosomes. However, there is little information about difference in efficiency of exosome isolation among these newly developed methods.

3.2. Collection of High-Quality and Uniform Exosomes In addition to the yield of exosomes, many other properties are affected by choice of isolation methods. Table 1 summarizes the advantages and disadvantages of each isolation method. Purity and physicochemical properties of exosomes are the major factors affected by different isolation methods. Our previous research showed that simple ultracentrifugation causes more contamination of proteins and aggregation of exosomes compared with density cushion and density gradient methods. ${ }^{56)}$ Therefore simple ultracentrifugation, which is the most commonly used method for exosome isolation, may not be suitable for therapeutic application in scenarios wherein these parameters affect efficacy. Additionally, polymer-based commercial reagents for exosome isolation are not suitable for therapeutic application because they are known to cause severe aggregation and contamination. ${ }^{56,71)}$ Recently, it was noted that there exist subpopulations in exosomes, which are different in their composition and size. ${ }^{72-74)}$ Subpopulations in the collected exosomes should be different among the isolation methods. Several studies indicated that composition of proteins and RNAs in exosomes are different among exosomes collected by different methods, ${ }^{71,75)}$ which may be caused by differences in subpopulations or contaminants. It is likely that therapeutic potentials are different among the subpopulations, although differences have not been reported yet. Other properties such as protein corona (that is, proteins adsorbed on the surface of nanoparticles) may also be affected by isolation methods. Although it is not clear whether protein corona is formed on exosomes, it was reported that the protein corona changes the properties of nanoparticles such as mechanisms of cellular uptake and clearance from blood circulation. ${ }^{76-78)}$

Overall, exosomes collected from different isolation methods are different in many properties. Thus for therapeutic application of exosomes, optimization of the isolation method is important to preserve properties of exosomes and to reduce risk for side effects induced by contaminants or specific subpopulations.

3.3. Optimization of Storage Conditions The International Society of Extracellular Vesicles recommends ${ }^{79)}$ that exosomes be suspended in phosphate buffered saline and stored at $-80^{\circ} \mathrm{C}$. It was previously shown that storage at higher temperatures decreased quantity of exosomes and their contents, whereas storage at $-80^{\circ} \mathrm{C}$ was associated with fewer changes. ${ }^{80,81)}$ It was shown that addition of trehalose protected exosomes from cryodamage. ${ }^{82}$ For therapeutic application, storage at higher temperatures is desirable because it does 
Table 1. Characteristics of Exosome Isolation Methods

\begin{tabular}{|c|c|c|c|}
\hline & Advantages & Disadvantages & References \\
\hline \multicolumn{4}{|l|}{ Ultracentrifugation-based methods } \\
\hline Simple pelleting & Scalable, low running cost & $\begin{array}{l}\text { High cost for equipment, aggregation, protein contami- } \\
\text { nation }\end{array}$ & 56) \\
\hline Density cushion method & High purity compared to simple pelleting & High cost for equipment, aggregation & 56) \\
\hline Density gradient method & High purity, gentle & $\begin{array}{l}\text { High cost for equipment, time-consuming, low sample } \\
\text { capacity }\end{array}$ & 56) \\
\hline \multicolumn{4}{|l|}{ Size-based separation } \\
\hline Ultrafiltration & Very scalable, fast & Low purity, damages by shear stress & $63)$ \\
\hline Size exclusion chromatography & High purity, gentle & Low sample capacity, dilution of samples & 64) \\
\hline \multicolumn{4}{|l|}{ Polymer-based methods } \\
\hline Polymer-based precipitation & Easy, scalable, requires no special equipment & Low purity, severe aggregation & $56,65)$ \\
\hline Aqueous two-phase system & Easy, scalable, requires no special equipment & Little information & 66) \\
\hline \multicolumn{4}{|l|}{ Affinity-based separation } \\
\hline Surface protein affinity method & High purity, can collect specific subpopulation & $\begin{array}{l}\text { High cost for reagent, damages on surface proteins } \\
\text { during elution }\end{array}$ & 67) \\
\hline $\begin{array}{l}\text { Phosphatidylserine affinity } \\
\text { method }\end{array}$ & Elution in a mild condition & High cost for reagent & $68)$ \\
\hline \multicolumn{4}{|l|}{ Others } \\
\hline Microfluidic systems & Low cost, high purity & Less scalable & $69,70)$ \\
\hline
\end{tabular}

not require special equipment. Lyophilization of exosomes may improve their stability at higher temperatures. In a patent of Kreke et $a l^{83)}$ it was shown that exosomes obtained from cardiosphere-derived cells by ultrafiltration can be lyophilized without significant loss of biological activity. However, it is not clear whether different types of exosomes can be lyophilized by the same methodology. Additionally, shelf-life of lyophilized exosomes remains unclear. Further research should be performed to reveal these points.

3.4. Improvement of Therapeutic Potential of Exosomes For overcoming low productivity of exosomes, improving their therapeutic potential can be one possible solution. Overexpression of molecules related to therapeutic effects of exosomes is a simple method to improve therapeutic potential. Several groups ${ }^{84,85}$ demonstrated that overexpression of miRNAs enhanced therapeutic effects of exosomes. It has been reported that overexpression of proteins that change expression profile of miRNAs and proteins also may improve therapeutic potential of exosomes ${ }^{86,87)}$ Modification of exosomes with functional molecules is also effective in increasing their therapeutic potential. In our previous study we demonstrated that modification of B16BL6-derived exosomes with CpG DNA, an immune adjuvant, was effective in decreasing the dose of exosomes required to induce cancer antigen-specific immune response by 10-100 fold compared with preceding studies in which unmodified exosomes were administered ${ }^{53}$ Hypoxia treatment also changed the composition of exosomes, and resulted in enhancement of their biological effects. ${ }^{88,89)}$ However, because these modifications may cause unwanted changes in exosomes, the effects and safety of modified exosomes should be evaluated independently.

3.5. Delivery of Exosomes Because the biological effect of exosomes is exerted by their uptake by target cells, elucidation and control of biodistribution of exosomes are required for the therapeutic application of exosomes. Our research showed that intravenously injected exosomes rapidly disappeared from blood circulation and accumulated in the liver, spleen, and lung. ${ }^{90,91)}$ In addition, we have demonstrated that exosomes are taken up by macrophages in the liver and spleen and that the negative charges of exosomes derived from phosphatidylserine contained in exosomal membrane play some roles in the recognition of the exosomes by macrophages. ${ }^{92,93)}$ In accordance with our study, other researchers have shown that intravenously injected exosomes mainly accumulated to the liver and spleen. ${ }^{94,95)}$ On the other hand, Grange et al. ${ }^{96)}$ showed that exosomes accumulated to the kidney when intravenously injected in acute kidney injury model mice. This change in the distribution of exosomes may be due to the enhanced vascular permeability in the kidney caused by injury and inflammation. ${ }^{97)}$ Wiklander et al. ${ }^{98)}$ investigated the biodistribution of exosomes following injection via different routes: intraperitoneal injection resulted in higher accumulation in pancreas and gastrointestinal tract compared with intravenous injection, whereas subcutaneous injection resulted in much lower accumulation of exosomes in all measured organs. In most cases, the majority of an injected exosomes dose is rapidly taken up by macrophages in the reticuloendothelial system irrespective of cell source and route of administration. ${ }^{55,98)}$ This rapid clearance of exosomes by macrophages limits systemic administration of exosomes. Although there are several reports showing that ligand modification of exosomes enhanced their accumulation in target organs, the amount of exosomes in the target organ was limited. ${ }^{99}$

\section{CONCLUSION}

Exosomes are expected to become effective therapeutic reagents for various diseases. However, there remain several challenges to their optimal use. In particular, methods for large-scale production must be developed. Methods for isolation and storage should be carefully optimized since they affect various factors of collected exosomes. Additionally, improvement of therapeutic potential and delivery efficiency of exosomes is needed. In this review, we summarized current knowledge about these challenges in the process of exosome production. The information in this review will be helpful to develop superior methods for production of exosome formulation. 
Acknowledgments This work was supported by Grant-inAid for Challenging Exploratory Research and Grant-in-Aid for Japan Society for the Promotion of Science (JSPS) Fellows from JSPS KAKENHI (Grant number 17K19390 and 17J09513).

Conflict of Interest The authors declare no conflict of interest.

\section{REFERENCES}

1) Théry C, Ostrowski M, Segura E. Membrane vesicles as conveyors of immune responses. Nat. Rev. Immunol., 9, 581-593 (2009).

2) Heijnen HF, Schiel AE, Fijnheer R, Geuze HJ, Sixma JJ. Activated platelets release two types of membrane vesicles: microvesicles by surface shedding and exosomes derived from exocytosis of multivesicular bodies and alpha-granules. Blood, 94, 3791-3799 (1999).

3) Baietti MF, Zhang Z, Mortier E, Melchior A, Degeest G, Geeraerts A, Ivarsson $Y$, Depoortere $F$, Coomans $C$, Vermeiren E, Zimmermann P, David G. Syndecan-syntenin-ALIX regulates the biogenesis of exosomes. Nat. Cell Biol., 14, 677-685 (2012).

4) Jackson CE, Scruggs BS, Schaffer JE, Hanson PI. Effects of inhibiting VPS4 support a general role for ESCRTs in extracellular vesicle biogenesis. Biophys. J., 113, 1342-1352 (2017).

5) Trajkovic K, Hsu C, Chiantia S, Rajendran L, Wenzel D, Wieland F, Schwille P, Brugger B, Simons M. Ceramide triggers budding of exosome vesicles into multivesicular endosomes. Science, 319, 1244-1247 (2008).

6) Ghossoub R, Lembo F, Rubio A, Gaillard CB, Bouchet J, Vitale N, Slavik J, Machala M, Zimmermann P. Syntenin-ALIX exosome biogenesis and budding into multivesicular bodies are controlled by ARF6 and PLD2. Nat. Commun., 5, 3477 (2014).

7) Kajimoto T, Okada T, Miya S, Zhang L, Nakamura S. Ongoing activation of sphingosine 1-phosphate receptors mediates maturation of exosomal multivesicular endosomes. Nat. Commun., 4, 2712 (2013).

8) Villarroya-Beltri C, Gutierrez-Vazquez C, Sanchez-Cabo F, PerezHernandez D, Vazquez J, Martin-Cofreces N, Martinez-Herrera DJ, Pascual-Montano A, Mittelbrunn M, Sanchez-Madrid F. Sumoylated hnRNPA2B1 controls the sorting of miRNAs into exosomes through binding to specific motifs. Nat. Commun., 4, 2980 (2013).

9) Gibbings DJ, Ciaudo C, Erhardt M, Voinnet O. Multivesicular bodies associate with components of miRNA effector complexes and modulate miRNA activity. Nat. Cell Biol., 11, 1143-1149 (2009).

10) Putz U, Howitt J, Lackovic J, Foot N, Kumar S, Silke J, Tan SS Nedd4 family-interacting protein 1 (Ndfip1) is required for the exosomal secretion of Nedd4 family proteins. J. Biol. Chem., 283, 32621-32627 (2008).

11) Liang Y, Eng WS, Colquhoun DR, Dinglasan RR, Graham DR, Mahal LK. Complex $N$-linked glycans serve as a determinant for exosome/microvesicle cargo recruitment. J. Biol. Chem., 289, 32526-32537 (2014).

12) Lötvall J, Hill AF, Hochberg F, Buzas EI, Di Vizio D, Gardiner C, Gho YS, Kurochkin IV, Mathivanan S, Quesenberry P, Sahoo S, Tahara H, Wauben MH, Witwer KW, Thery C. Minimal experimental requirements for definition of extracellular vesicles and their functions: a position statement from the International Society for Extracellular Vesicles. Journal of Extracellular Vesicles, 3, 26913 (2014).

13) Valadi H, Ekstrom K, Bossios A, Sjostrand M, Lee JJ, Lotvall JO. Exosome-mediated transfer of mRNAs and microRNAs is a novel mechanism of genetic exchange between cells. Nat. Cell Biol., 9, 654-659 (2007).

14) Taylor DD, Zacharias W, Gercel-Taylor C. Exosome isolation for proteomic analyses and RNA profiling. Methods Mol. Biol., 728, 235-246 (2011).
15) Llorente A, Skotland T, Sylvanne T, Kauhanen D, Rog T, Orlowski A, Vattulainen I, Ekroos K, Sandvig K. Molecular lipidomics of exosomes released by PC-3 prostate cancer cells. Biochim. Biophys. Acta, 1831, 1302-1309 (2013).

16) Laulagnier K, Motta C, Hamdi S, Roy S, Fauvelle F, Pageaux JF, Kobayashi T, Salles JP, Perret B, Bonnerot C, Record M. Mast cell- and dendritic cell-derived exosomes display a specific lipid composition and an unusual membrane organization. Biochem. J., 380, 161-171 (2004).

17) Peinado H, Aleckovic M, Lavotshkin S, Matei I, Costa-Silva B, Moreno-Bueno G, Hergueta-Redondo M, Williams C, GarciaSantos G, Ghajar C, Nitadori-Hoshino A, Hoffman C, Badal K, Garcia BA, Callahan MK, Yuan J, Martins VR, Skog J, Kaplan RN, Brady MS, Wolchok JD, Chapman PB, Kang Y, Bromberg J, Lyden D. Melanoma exosomes educate bone marrow progenitor cells toward a pro-metastatic phenotype through MET. Nat. Med., 18, 883-891 (2012)

18) Matsumoto A, Takahashi Y, Nishikawa M, Sano K, Morishita M, Charoenviriyakul C, Saji H, Takakura Y. Accelerated growth of B16BL6 tumor in mice through efficient uptake of their own exosomes by B16BL6 cells. Cancer Sci., 108, 1803-1810 (2017).

19) Santos JC, Lima NDS, Sarian LO, Matheu A, Ribeiro ML, Derchain SFM. Exosome-mediated breast cancer chemoresistance via miR-155 transfer. Sci. Rep., 8, 829 (2018).

20) Azmi AS, Bao B, Sarkar FH. Exosomes in cancer development, metastasis, and drug resistance: a comprehensive review. Cancer Metastasis Rev., 32, 623-642 (2013).

21) Kapustin AN, Chatrou ML, Drozdov I, Zheng Y, Davidson SM, Soong D, Furmanik M, Sanchis P, De Rosales RT, Alvarez-Hernandez D, Shroff R, Yin X, Muller K, Skepper JN, Mayr M, Reutelingsperger CP, Chester A, Bertazzo S, Schurgers LJ, Shanahan CM. Vascular smooth muscle cell calcification is mediated by regulated exosome secretion. Circ. Res., 116, 1312-1323 (2015).

22) Ying W, Riopel M, Bandyopadhyay G, Dong Y, Birmingham A, Seo JB, Ofrecio JM, Wollam J, Hernandez-Carretero A, Fu W, Li P, Olefsky JM. Adipose tissue macrophage-derived exosomal miRNAs can modulate in vivo and in vitro insulin sensitivity. Cell, 171, 372-384.e12 (2017)

23) Yuyama K, Igarashi Y. Exosomes as carriers of Alzheimer's amyloid-ss. Frontiers in Neuroscience, 11, 229 (2017).

24) Chamberlain G, Fox J, Ashton B, Middleton J. Concise review: mesenchymal stem cells: their phenotype, differentiation capacity, immunological features, and potential for homing. Stem Cells, 25, 2739-2749 (2007).

25) Lai RC, Arslan F, Lee MM, Sze NS, Choo A, Chen TS, Salto-Tellez M, Timmers L, Lee CN, El Oakley RM, Pasterkamp G, de Kleijn DP, Lim SK. Exosome secreted by MSC reduces myocardial ischemia/reperfusion injury. Stem Cell Res., 4, 214-222 (2010).

26) Wang X, Gu H, Qin D, Yang L, Huang W, Essandoh K, Wang Y, Caldwell CC, Peng T, Zingarelli B, Fan GC. Exosomal miR-223 contributes to mesenchymal stem cell-elicited cardioprotection in polymicrobial sepsis. Sci. Rep., 5, 13721 (2015).

27) Teng X, Chen L, Chen W, Yang J, Yang Z, Shen Z. Mesenchymal stem cell-derived exosomes improve the microenvironment of infarcted myocardium contributing to angiogenesis and anti-inflammation. Cell. Physiol. Biochem., 37, 2415-2424 (2015).

28) Lou G, Chen Z, Zheng M, Liu Y. Mesenchymal stem cell-derived exosomes as a new therapeutic strategy for liver diseases. Exp. Mol. Med., 49, e346 (2017).

29) Lv LL, Wu WJ, Feng Y, Li ZL, Tang TT, Liu BC. Therapeutic application of extracellular vesicles in kidney disease: promises and challenges. J. Cell. Mol. Med., 22, 728-737 (2018).

30) Lee C, Mitsialis SA, Aslam M, Vitali SH, Vergadi E, Konstantinou G, Sdrimas K, Fernandez-Gonzalez A, Kourembanas S. Exosomes mediate the cytoprotective action of mesenchymal stromal cells on hypoxia-induced pulmonary hypertension. Circulation, 126, 
2601-2611 (2012).

31) Xin H, Li Y, Cui Y, Yang JJ, Zhang ZG, Chopp M. Systemic administration of exosomes released from mesenchymal stromal cells promote functional recovery and neurovascular plasticity after stroke in rats. J. Cereb. Blood Flow Metab., 33, 1711-1715 (2013).

32) Yu B, Shao H, Su C, Jiang Y, Chen X, Bai L, Zhang Y, Li Q, Zhang $\mathrm{X}, \mathrm{Li} \mathrm{X}$. Exosomes derived from MSCs ameliorate retinal laser injury partially by inhibition of MCP-1. Sci. Rep., 6, 34562 (2016).

33) Zhang B, Wang M, Gong A, Zhang X, Wu X, Zhu Y, Shi H, Wu L, Zhu W, Qian H, Xu W. HucMSC-exosome mediated-Wnt4 signaling is required for cutaneous wound healing. Stem Cells, 33, 2158-2168 (2015).

34) Wang L, Hu L, Zhou X, Xiong Z, Zhang C, Shehada HMA, Hu B, Song J, Chen L. Exosomes secreted by human adipose mesenchymal stem cells promote scarless cutaneous repair by regulating extracellular matrix remodelling. Sci. Rep., 7, 13321 (2017).

35) Sun L, Xu R, Sun X, Duan Y, Han Y, Zhao Y, Qian H, Zhu W, Xu W. Safety evaluation of exosomes derived from human umbilical cord mesenchymal stromal cell. Cytotherapy, 18, 413-422 (2016).

36) Liu X, Li Q, Niu X, Hu B, Chen S, Song W, Ding J, Zhang C, Wang Y. Exosomes secreted from human-induced pluripotent stem cellderived mesenchymal stem cells prevent osteonecrosis of the femoral head by promoting angiogenesis. Int. J. Biol. Sci., 13, 232-244 (2017).

37) Zhu Y, Wang Y, Zhao B, Niu X, Hu B, Li Q, Zhang J, Ding J, Chen Y, Wang Y. Comparison of exosomes secreted by induced pluripotent stem cell-derived mesenchymal stem cells and synovial membrane-derived mesenchymal stem cells for the treatment of osteoarthritis. Stem Cell Research \& Therapy, 8, 64 (2017).

38) Wang Y, Zhang L, Li Y, Chen L, Wang X, Guo W, Zhang X, Qin G, He SH, Zimmerman A, Liu Y, Kim IM, Weintraub NL, Tang Y. Exosomes/microvesicles from induced pluripotent stem cells deliver cardioprotective miRNAs and prevent cardiomyocyte apoptosis in the ischemic myocardium. Int. J. Cardiol., 192, 61-69 (2015).

39) Khan M, Nickoloff E, Abramova T, Johnson J, Verma SK, Krishnamurthy P, Mackie AR, Vaughan E, Garikipati VN, Benedict C, Ramirez V, Lambers E, Ito A, Gao E, Misener S, Luongo T, Elrod J, Qin G, Houser SR, Koch WJ, Kishore R. Embryonic stem cellderived exosomes promote endogenous repair mechanisms and enhance cardiac function following myocardial infarction. Circ. Res., 117, 52-64 (2015).

40) Vrijsen KR, Maring JA, Chamuleau SA, Verhage V, Mol EA, Deddens JC, Metz CH, Lodder K, van Eeuwijk EC, van Dommelen SM, Doevendans PA, Smits AM, Goumans MJ, Sluijter JP. Exosomes from cardiomyocyte progenitor cells and mesenchymal stem cells stimulate angiogenesis via EMMPRIN. Advanced Healthcare Materials, 5, 2555-2565 (2016).

41) Admyre C, Johansson SM, Qazi KR, Filen JJ, Lahesmaa R, Norman M, Neve EP, Scheynius A, Gabrielsson S. Exosomes with immune modulatory features are present in human breast milk. J. Immunol., 179, 1969-1978 (2007).

42) Arntz OJ, Pieters BC, Oliveira MC, Broeren MG, Bennink MB, de Vries M, van Lent PL, Koenders MI, van den Berg WB, van der Kraan PM, van de Loo FA. Oral administration of bovine milk derived extracellular vesicles attenuates arthritis in two mouse models. Mol. Nutr. Food Res., 59, 1701-1712 (2015)

43) Samuel M, Chisanga D, Liem M, Keerthikumar S, Anand S, Ang CS, Adda CG, Versteegen E, Jois M, Mathivanan S. Bovine milkderived exosomes from colostrum are enriched with proteins implicated in immune response and growth. Sci. Rep., 7, 5933 (2017).

44) Mu J, Zhuang X, Wang Q, Jiang H, Deng ZB, Wang B, Zhang L, Kakar S, Jun Y, Miller D, Zhang HG. Interspecies communication between plant and mouse gut host cells through edible plant derived exosome-like nanoparticles. Mol. Nutr. Food Res., 58, 1561-1573 (2014)

45) $\mathrm{Ju} \mathrm{S,} \mathrm{Mu} \mathrm{J,} \mathrm{Dokland} \mathrm{T,} \mathrm{Zhuang} \mathrm{X,} \mathrm{Wang} \mathrm{Q,} \mathrm{Jiang} \mathrm{H,} \mathrm{Xiang} \mathrm{X,}$
Deng ZB, Wang B, Zhang L, Roth M, Welti R, Mobley J, Jun Y, Miller D, Zhang HG. Grape exosome-like nanoparticles induce intestinal stem cells and protect mice from DSS-induced colitis. Mol. Ther., 21, 1345-1357 (2013).

46) Théry C, Regnault A, Garin J, Wolfers J, Zitvogel L, RicciardiCastagnoli P, Raposo G, Amigorena S. Molecular characterization of dendritic cell-derived exosomes. Selective accumulation of the heat shock protein hsc73. J. Cell Biol., 147, 599-610 (1999).

47) Théry C, Boussac M, Veron P, Ricciardi-Castagnoli P, Raposo G, Garin J, Amigorena S. Proteomic analysis of dendritic cell-derived exosomes: a secreted subcellular compartment distinct from apoptotic vesicles. J. Immunol., 166, 7309-7318 (2001).

48) Andre F, Chaput N, Schartz NE, Flament C, Aubert N, Bernard J, Lemonnier F, Raposo G, Escudier B, Hsu DH, Tursz T, Amigorena S, Angevin E, Zitvogel L. Exosomes as potent cell-free peptidebased vaccine. I. Dendritic cell-derived exosomes transfer functional MHC class I/peptide complexes to dendritic cells. J. Immunol., 172, 2126-2136 (2004).

49) Admyre C, Johansson SM, Paulie S, Gabrielsson S. Direct exosome stimulation of peripheral human T cells detected by ELISPOT. Eur. J. Immunol., 36, 1772-1781 (2006).

50) Théry C, Duban L, Segura E, Veron P, Lantz O, Amigorena S. Indirect activation of naive $\mathrm{CD}^{+} \mathrm{T}$ cells by dendritic cell-derived exosomes. Nat. Immunol., 3, 1156-1162 (2002).

51) Segura E, Nicco C, Lombard B, Veron P, Raposo G, Batteux F, Amigorena S, Thery C. ICAM-1 on exosomes from mature dendritic cells is critical for efficient naive T-cell priming. Blood, 106, 216-223 (2005).

52) Viaud S, Terme M, Flament C, Taieb J, Andre F, Novault S, Escudier B, Robert C, Caillat-Zucman S, Tursz T, Zitvogel L, Chaput N. Dendritic cell-derived exosomes promote natural killer cell activation and proliferation: a role for NKG2D ligands and IL-15R $\alpha$. PLoS ONE, 4, e4942 (2009).

53) Morishita M, Takahashi Y, Matsumoto A, Nishikawa M, Takakura Y. Exosome-based tumor antigens-adjuvant co-delivery utilizing genetically engineered tumor cell-derived exosomes with immunostimulatory CpG DNA. Biomaterials, 111, 55-65 (2016).

54) Morishita M, Takahashi Y, Nishikawa M, Ariizumi R, Takakura Y. Enhanced class I tumor antigen presentation via cytosolic delivery of exosomal cargos by tumor-cell-derived exosomes displaying a pH-sensitive fusogenic peptide. Mol. Pharm., 14, 4079-4086 (2017). 55) Charoenviriyakul C, Takahashi Y, Morishita M, Matsumoto A, Nishikawa M, Takakura Y. Cell type-specific and common characteristics of exosomes derived from mouse cell lines: yield, physicochemical properties, and pharmacokinetics. Eur. J. Pharm. Sci., 96, 316-322 (2017).

56) Yamashita T, Takahashi Y, Nishikawa M, Takakura Y. Effect of exosome isolation methods on physicochemical properties of exosomes and clearance of exosomes from the blood circulation. Eur. J. Pharm. Biopharm., 98, 1-8 (2016).

57) Willis GR, Kourembanas S, Mitsialis SA. Toward exosome-based therapeutics: isolation, heterogeneity, and fit-for-purpose potency. Frontiers in Cardiovascular Medicine, 4, 63 (2017).

58) Riches A, Campbell E, Borger E, Powis S. Regulation of exosome release from mammary epithelial and breast cancer cells-a new regulatory pathway. Eur. J. Cancer, 50, 1025-1034 (2014).

59) Watson DC, Bayik D, Srivatsan A, Bergamaschi C, Valentin A, Niu G, Bear J, Monninger M, Sun M, Morales-Kastresana A, Jones JC, Felber BK, Chen X, Gursel I, Pavlakis GN. Efficient production and enhanced tumor delivery of engineered extracellular vesicles. Biomaterials, 105, 195-205 (2016).

60) Harmati M, Tarnai Z, Decsi G, Kormondi S, Szegletes Z, Janovak L, Dekany I, Saydam O, Gyukity-Sebestyen E, Dobra G, Nagy I, Nagy K, Buzas K. Stressors alter intercellular communication and exosome profile of nasopharyngeal carcinoma cells. J. Oral Pathol. Med., 46, 259-266 (2017). 
61) King HW, Michael MZ, Gleadle JM. Hypoxic enhancement of exosome release by breast cancer cells. BMC Cancer, 12, 421 (2012).

62) Parolini I, Federici C, Raggi C, Lugini L, Palleschi S, De Milito A, Coscia C, Iessi E, Logozzi M, Molinari A, Colone M, Tatti M, Sargiacomo M, Fais S. Microenvironmental $\mathrm{pH}$ is a key factor for exosome traffic in tumor cells. J. Biol. Chem., 284, 34211-34222 (2009).

63) Heinemann ML, Ilmer M, Silva LP, Hawke DH, Recio A, Vorontsova MA, Alt E, Vykoukal J. Benchtop isolation and characterization of functional exosomes by sequential filtration. J. Chromatogr. A, 1371, 125-135 (2014).

64) Böing AN, van der Pol E, Grootemaat AE, Coumans FA, Sturk A, Nieuwland R. Single-step isolation of extracellular vesicles by size-exclusion chromatography. Journal of Extracellular Vesicles, $\mathbf{3}$, 23430 (2014).

65) Weng Y, Sui Z, Shan Y, Hu Y, Chen Y, Zhang L, Zhang Y. Effective isolation of exosomes with polyethylene glycol from cell culture supernatant for in-depth proteome profiling. Analyst, 141, 4640-4646 (2016).

66) Shin H, Han C, Labuz JM, Kim J, Kim J, Cho S, Gho YS, Takayama S, Park J. High-yield isolation of extracellular vesicles using aqueous two-phase system. Sci. Rep., 5, 13103 (2015).

67) Oksvold MP, Neurauter A, Pedersen KW. Magnetic bead-based isolation of exosomes. Methods Mol. Biol., 1218, 465-481 (2015).

68) Nakai W, Yoshida T, Diez D, Miyatake Y, Nishibu T, Imawaka N, Naruse K, Sadamura Y, Hanayama R. A novel affinity-based method for the isolation of highly purified extracellular vesicles. Sci. Rep., 6, 33935 (2016).

69) Lee K, Shao H, Weissleder R, Lee H. Acoustic purification of extracellular microvesicles. ACS Nano, 9, 2321-2327 (2015).

70) Liu C, Guo J, Tian F, Yang N, Yan F, Ding Y, Wei J, Hu G, Nie G, Sun J. Field-free isolation of exosomes from extracellular vesicles by microfluidic viscoelastic flows. ACS Nano, 11, 6968-6976 (2017).

71) Van Deun J, Mestdagh P, Sormunen R, Cocquyt V, Vermaelen K, Vandesompele J, Bracke M, De Wever O, Hendrix A. The impact of disparate isolation methods for extracellular vesicles on downstream RNA profiling. Journal of Extracellular Vesicles, 3, 24858 (2014).

72) Bobrie A, Colombo M, Krumeich S, Raposo G, Thery C. Diverse subpopulations of vesicles secreted by different intracellular mechanisms are present in exosome preparations obtained by differential ultracentrifugation. Journal of Extracellular Vesicles, 1, 18397 (2012).

73) Willms E, Johansson HJ, Mager I, Lee Y, Blomberg KE, Sadik M, Alaarg A, Smith CI, Lehtio J, El Andaloussi S, Wood MJ, Vader P. Cells release subpopulations of exosomes with distinct molecular and biological properties. Sci. Rep., 6, 22519 (2016).

74) Kowal J, Arras G, Colombo M, Jouve M, Morath JP, PrimdalBengtson B, Dingli F, Loew D, Tkach M, Thery C. Proteomic comparison defines novel markers to characterize heterogeneous populations of extracellular vesicle subtypes. Proc. Natl. Acad. Sci. U.S.A., 113, E968-E977 (2016).

75) Tauro BJ, Greening DW, Mathias RA, Ji H, Mathivanan S, Scott AM, Simpson RJ. Comparison of ultracentrifugation, density gradient separation, and immunoaffinity capture methods for isolating human colon cancer cell line LIM1863-derived exosomes. Methods, 56, 293-304 (2012)

76) Lesniak A, Fenaroli F, Monopoli MP, Aberg C, Dawson KA, Salvati A. Effects of the presence or absence of a protein corona on silica nanoparticle uptake and impact on cells. ACS Nano, 6, 5845-5857 (2012).

77) Schöttler S, Becker G, Winzen S, Steinbach T, Mohr K, Landfester $\mathrm{K}$, Mailander V, Wurm FR. Protein adsorption is required for stealth effect of poly(ethylene glycol)- and poly(phosphoester)coated nanocarriers. Nat. Nanotechnol., 11, 372-377 (2016).

78) Digiacomo L, Cardarelli F, Pozzi D, Palchetti S, Digman MA, Gratton E, Capriotti AL, Mahmoudi M, Caracciolo G. An apo- lipoprotein-enriched biomolecular corona switches the cellular uptake mechanism and trafficking pathway of lipid nanoparticles. Nanoscale, 9, 17254-17262 (2017).

79) Witwer KW, Buzas EI, Bemis LT, Bora A, Lasser C, Lotvall J, Nolte-'t Hoen EN, Piper MG, Sivaraman S, Skog J, Thery C, Wauben MH, Hochberg F. Standardization of sample collection, isolation and analysis methods in extracellular vesicle research. Journal of Extracellular Vesicles, 2, 20360 (2013).

80) Zhou H, Yuen PS, Pisitkun T, Gonzales PA, Yasuda H, Dear JW, Gross P, Knepper MA, Star RA. Collection, storage, preservation, and normalization of human urinary exosomes for biomarker discovery. Kidney Int., 69, 1471-1476 (2006).

81) Munagala R, Aqil F, Jeyabalan J, Gupta RC. Bovine milk-derived exosomes for drug delivery. Cancer Lett., 371, 48-61 (2016).

82) Bosch S, de Beaurepaire L, Allard M, Mosser M, Heichette C, Chretien D, Jegou D, Bach JM. Trehalose prevents aggregation of exosomes and cryodamage. Sci. Rep., 6, 36162 (2016).

83) Kreke M, Smith R, Hanscome P, Peck K, Ibrahim A. Processes for producing stable exosome formulations. US Patent 20160158291A1, (2016).

84) Qu Y, Zhang Q, Cai X, Li F, Ma Z, Xu M, Lu L. Exosomes derived from miR-181-5p-modified adipose-derived mesenchymal stem cells prevent liver fibrosis via autophagy activation. J. Cell. Mol. Med., 21, 2491-2502 (2017).

85) Zhang J, Ma J, Long K, Qiu W, Wang Y, Hu Z, Liu C, Luo Y, Jiang A, Jin L, Tang Q, Wang X, Li X, Li M. Overexpression of exosomal cardioprotective miRNAs mitigates hypoxia-induced H9c2 cells apoptosis. Int. J. Mol. Sci., 18, 711 (2017).

86) Yu B, Kim HW, Gong M, Wang J, Millard RW, Wang Y, Ashraf M, Xu M. Exosomes secreted from GATA-4 overexpressing mesenchymal stem cells serve as a reservoir of anti-apoptotic microRNAs for cardioprotection. Int. J. Cardiol., 182, 349-360 (2015).

87) Yang MQ, Du Q, Varley PR, Goswami J, Liang Z, Wang R, Li H, Stolz DB, Geller DA. Interferon regulatory factor 1 priming of tumour-derived exosomes enhances the antitumour immune response. Br. J. Cancer, 118, 62-71 (2018)

88) Cui GH, Wu J, Mou FF, Xie WH, Wang FB, Wang QL, Fang J, Xu YW, Dong YR, Liu JR, Guo HD. Exosomes derived from hypoxiapreconditioned mesenchymal stromal cells ameliorate cognitive decline by rescuing synaptic dysfunction and regulating inflammatory responses in APP/PS1 mice. FASEB J., 32, 654-668 (2018).

89) Lamichhane TN, Leung CA, Douti LY, Jay SM. Ethanol induces enhanced vascularization bioactivity of endothelial cell-derived extracellular vesicles via regulation of microRNAs and long non-coding RNAs. Scientific Reports, 7, 13794 (2017).

90) Takahashi Y, Nishikawa M, Shinotsuka H, Matsui Y, Ohara S, Imai T, Takakura Y. Visualization and in vivo tracking of the exosomes of murine melanoma B16-BL6 cells in mice after intravenous injection. J. Biotechnol., 165, 77-84 (2013).

91) Morishita M, Takahashi Y, Nishikawa M, Sano K, Kato K, Yamashita T, Imai T, Saji H, Takakura Y. Quantitative analysis of tissue distribution of the B16BL6-derived exosomes using a streptavidin-lactadherin fusion protein and iodine-125-labeled biotin derivative after intravenous injection in mice. J. Pharm. Sci., 104, 705-713 (2015)

92) Imai T, Takahashi $Y$, Nishikawa M, Kato K, Morishita M, Yamashita T, Matsumoto A, Charoenviriyakul C, Takakura Y. Macrophagedependent clearance of systemically administered B16BL6-derived exosomes from the blood circulation in mice. Journal of Extracellular Vesicles, 4, 26238 (2015).

93) Matsumoto A, Takahashi Y, Nishikawa M, Sano K, Morishita M, Charoenviriyakul C, Saji H, Takakura Y. Role of phosphatidylserine-derived negative surface charges in the recognition and uptake of intravenously injected B16BL6-derived exosomes by macrophages. J. Pharm. Sci., 106, 168-175 (2017).

94) Smyth T, Kullberg M, Malik N, Smith-Jones P, Graner MW, An- 
chordoquy TJ. Biodistribution and delivery efficiency of unmodified tumor-derived exosomes. J. Control. Release, 199, 145-155 (2015).

95) Lai CP, Mardini O, Ericsson M, Prabhakar S, Maguire C, Chen JW, Tannous BA, Breakefield XO. Dynamic biodistribution of extracellular vesicles in vivo using a multimodal imaging reporter. $A C S$ Nano, 8, 483-494 (2014).

96) Grange C, Tapparo M, Bruno S, Chatterjee D, Quesenberry PJ, Tetta C, Camussi G. Biodistribution of mesenchymal stem cellderived extracellular vesicles in a model of acute kidney injury monitored by optical imaging. Int. J. Mol. Med., 33, 1055-1063 (2014).

97) Claesson-Welsh L. Vascular permeability—the essentials. Ups. J.
Med. Sci., 120, 135-143 (2015).

98) Wiklander OP, Nordin JZ, O'Loughlin A, Gustafsson Y, Corso G, Mager I, Vader P, Lee Y, Sork H, Seow Y, Heldring N, AlvarezErviti L, Smith CI, Le Blanc K, Macchiarini P, Jungebluth P, Wood MJ, Andaloussi SE. Extracellular vesicle in vivo biodistribution is determined by cell source, route of administration and targeting. Journal of Extracellular Vesicles, 4, 26316 (2015).

99) Ohno S, Takanashi M, Sudo K, Ueda S, Ishikawa A, Matsuyama N, Fujita K, Mizutani T, Ohgi T, Ochiya T, Gotoh N, Kuroda M. Systemically injected exosomes targeted to EGFR deliver antitumor microRNA to breast cancer cells. Mol. Ther., 21, 185-191 (2013). 